\title{
CTLA4 Haploinsufficiency
}

National Cancer Institute

\section{Source}

National Cancer Institute. CT LA4 Haploinsufficiency. NCI Thesaurus. Code C126341.

A somatic mutation in the CT LA4 gene resulting in only a single functional gene.

Haploinsufficiency for CT LA4 is associated with autoimmune lymphoproliferative syndrome, type $\mathrm{V}$. 